\title{
Technical Efficiency of Boro Rice Production in Meherpur District of Bangladesh: A Stochastic Frontier Approach
}

\author{
Md. Nehal Hasnain, Md. Elias Hossain, Md. Khairul Islam \\ Department of Economics, University of Rajshahi, Rajshahi-6205, Bangladesh \\ Email address: \\ nehalhasnainshoron@ymail.com (M. N. Hasnain), khairul06eco@gmail.com (M. K. Islam), eliaseco@ru.ac.bd (M. E. Hossain) \\ To cite this article: \\ Md. Nehal Hasnain, Md. Elias Hossain, Md. Khairul Islam. Technical Efficiency of Boro Rice Production in Meherpur District of \\ Bangladesh: A Stochastic Frontier Approach. American Journal of Agriculture and Forestry. Vol. 3, No. 2, 2015, pp. 31-37. \\ doi: 10.11648/j.ajaf.20150302.14
}

\begin{abstract}
Although rice is the main crop in Bangladesh and the country is ranked as the sixth largest rice producer in the world, researchers observe that rice is not produced with full efficiency in the country. It is also observed that owing to the application of high yielding variety seeds, chemical fertilizer, pesticide, and irrigation, productivity of rice in Bangladesh has increased in the recent years though it is still lower compared to other Asian countries. A review of existing literature reveals that so far little attention has been given by the researchers in investigating the efficiency of rice production in Bangladesh. Thus, the objective of the present study is to analyze the technical efficiency of rice production in Bangladesh using data from boro rice farmers. Required data are collected from 115 boro rice producing farmers of Meherpur district selected using multistage random sampling procedure. In analyzing the data, farm specific technical efficiency scores are estimated using the Translog Stochastic Frontier Production function approach. The study found that technical efficiency of boro rice farms in Meherpur district is $89.5 \%$. It is also found that 'labor', 'fertilizer and pesticide', 'seed' and 'irrigation' are the significant factors that affect the level of technical efficiency while 'farm size' and 'ploughing cost' are found insignificant in affecting technical efficiency of boro rice production in the study area. The results indicate that boro rice farms in the study area have been operating below the maximum level of production frontier and given the available technology, farmers can increase their production by $10.5 \%$ through increasing the use of labor, seed and irrigation inputs and also by using proper doses of fertilizer and pesticide inputs.
\end{abstract}

Keywords: Boro Rice, Technical Efficiency, Stochastic Frontier Approach, Bangladesh

\section{Introduction}

Agriculture is one of the most important sectors of Bangladesh economy (Nargis and Lee, 2013). The sector contributes around $16.77 \%$ to the gross domestic product (GDP) of the country and employs around $47.5 \%$ of the total labor force $(\mathrm{GoB}, 2014)$. Moreover, the sector feeds up around 160 million people of the country and provides survival and nutrition for the farm households of rural areas (GoB, 2014). In addition, this sector provides raw materials to agro-based and other industries operating in the country.

The main agricultural commodities in Bangladesh are rice, wheat, maize, jute, sugarcane, potato, vegetables, oilseeds, pulses, tea, etc. Among these crops, rice is widely cultivated all over the country throughout the year. In Bangladesh, rice is grown in three distinct seasons: boro (post-monsoon rice) from January to June, aus (pre-monsoon rice) from April to August and aman (monsoon rice) from August to December (Nargis and Lee, 2013). Of these three types of rice, boro alone comprises of about $55 \%$ of total food grain production. According to the report of the Bureau of Statistics of Bangladesh (BBS, 2010) productivity of boro rice per unit of land is higher (3.84 MT per hectare) compared to aus (1.76 MT per hectare) and aman (2.16 MT per hectare).

Rice yield in Bangladesh has increased at a significant rate as a result of introducing the use of high yielding seed varieties, fertilizers, pesticides, irrigation and mechanized cultivation system. Rice production has increased by $23.78 \%$ in fiscal year 2012-13 compared to fiscal year 2006-07 (BBS, 2013). However, until now the rate of growth of rice production in the country is lower than the rate of growth of demand for rice in the country. To meet additional demand, the country has to import rice almost every year in the previous decades (Nargis and Lee, 2013). For example, Bangladesh imported 18.72 lakh metric tons of food grains in fiscal year 2012-13 (GoB, 2014). To the opinion of some researchers, Bangladesh would not have to import rice if productivity could be enhanced through increasing technical 
efficiency in production (Hossain and Rahman, 2012).

However, Bangladesh agriculture has already been operating at its land frontier and there is little or no scope to expand cultivable land to meet increasing demand for food for its ever-increasing population (Hossain and Rahman, 2012). Moreover, average farm size in Bangladesh is relatively smaller compared to other countries due to existing ownership and inheritance system in the country and in many cases it becomes very difficult to adopt modern agricultural technologies. Again, there is lack of information and awareness among marginal farmers about the efficient use of inputs and proper cultivation methods of rice production. Given these situations, measurement of technical efficiency of rice production is an important issue in Bangladesh agriculture from the standpoint of agricultural development. This would provide pertinent information about the existing inefficiencies and facilitate to make sound policies related to management decision, resource allocation and institutional development toward enhancing efficiency of rice production in the country (Nargis and Lee, 2013).

Thus, the objectives of this study are to determine the level of technical efficiency of boro rice production in Meherpur district of Bangladesh and to assess the effects of the key inputs on technical efficiency of boro rice production in the study area.

\section{Literature Review}

A comprehensive review of literature regarding different aspects of technical efficiency of agricultural production in the context of Bangladesh as well as in other countries has been done.

Khan et al. (2010) examined the technical efficiency of rice production and its determinants in Jamalpur district of Bangladesh. Through using random sampling technique a total of 150 rice farmers were selected for the study and a stochastic production frontier approach was employed to estimate technical efficiency and determinants of efficiency in boro and aman rice production. The study found that the mean technical efficiency of boro rice production in the study area is $95 \%$ and in the case of aman rice production it is $91 \%$. The study also found that younger farmers are more efficient than elderly farmers. Moreover, the study found that education and experience of the farmers substantially reduce farm inefficiencies in the study area. Hasan (2008) conducted a study in sadar upazila of Dinajpur and Panchagarh districts of Bangladesh to estimate costs, returns and economic efficiency of boro rice farming using the Cobb-Douglas stochastic frontier production function taking 100 farm households from each district. The study found that average technical efficiency of boro rice farming is 0.84 in Dinajpur district and 0.80 Panchagarh district.

Mohapatra (2013) estimated the technical efficiency scores and the factors of inefficiency of paddy production in Odisha. Using both Cobb-Douglas and Translog production function approach this study found mean technical efficiency as $97.04 \%$. It also found that farming experience and high school as well as college education have significant and positive contribution in improving the technical efficiency.

Hossain and Rahman (2012) estimated technical efficiency of rice farmers in Naogaon district of Bangladesh using stochastic frontier approach. The study found that the mean technical efficiency of rice farming is $79.58 \%$ in the study area. The study observed that appropriate use of labor, seed, fertilizer, insecticide and irrigation may increase the level of technical efficiency of rice production in the study area. Shantha et al. (2013) investigated the technical efficiency of rice farming in a major irrigation scheme in Sri Lanka. A total of 357 paddy farmers under Nagadeepa reservoir were selected randomly for collecting relevant information. Applying the translog stochastic frontier production function, the study found that average technical efficiency of selected farmers is $72.80 \%$.

Tijani (2006) estimated technical efficiency of rice farms in Osun State of Nigeria and identified some socioeconomic factors which influence productive efficiency. In this study, stochastic frontier production function approach was applied to estimate the level of production efficiency. The findings of the study revealed that the level of technical efficiency in the study area ranges from $29.4 \%$ to $98.2 \%$ with a mean efficiency of $86.6 \%$. It is also found that the level of efficiencies is significantly and positively correlated with the application of traditional land preparation methods and offfarm income.

Chirwa (2007) explored technical efficiency among smallholder maize farmers in Malawi using Cobb-Douglas stochastic frontier production function. The study identified the sources of inefficiency using farm level data. It is found that smallholder maize farmers in Malawi are inefficient and the average efficiency score is only $46.23 \%$ in the study area. It is also found that $79 \%$ of the plots have efficiency scores below $70 \%$.

\section{Methodology}

\subsection{Study Area and Data Collection}

The present study is mainly based on primary data. Using multistage random sampling technique, required data are collected from a total of 115 boro rice producing farmers. The study is carried out in four villages, namely, Chandpur and Shibpur of Kutubpur Union, and Rajnagar and Borshibaria of Pirojpur Union under the Sadar Upazila of Meherpur district in Bangladesh.

\subsection{Concept of Technical Efficiency}

Technical efficiency of a farm is the ratio of farm's actual output to the technically maximum possible output, at given level of resources (Battese and Coelli, 1988; Adedejil et al., 2013). It can be classified broadly into three categories, namely, deterministic parametric estimation, stochastic parametric estimation and non-parametric mathematical programming (Udo and Akintola, 2001). Parametric frontier approach assumes functional form on the production function 
and makes assumptions about the data. The most common functional forms include the Cobb-Douglas, Constant Elasticity of Substitution (CES) and Translog production functions. Deterministic frontiers assume that all the deviations from the frontier are a result of firms' inefficiency, while stochastic frontiers assume that part of the deviation from the frontier is due to random events (reflecting measurement errors and statistical noise) and part is due to farm specific inefficiency (Forsund et al. 1980; Battese, 1992 and Coelli et al., 1998). On the other hand, nonparametric frontier assumes no functional form on the production frontiers and does not make assumptions about the error term. It uses linear programming approaches. The most popular nonparametric approach is the Data Envelopment Analysis (DEA).

The concept of efficiency of farms has widely been studied by a number of researchers. Most of the studies estimated technical efficiency using the stochastic frontier production function approach (Bravo-Ureta and Pinheiro, 1993; Parikh and Shah, 1994; Ajibefun and Abdulkadri, 1999; Ajibefun and Daramola, 1999; Sharma et al., 1999 and Ajibefun et al., 2002). Following these studies the stochastic parametric model is formulated in this study to analyze the technical efficiency of boro rice production in the study area.

\subsection{Stochastic Frontier Production Function}

The stochastic frontier model decomposes the error term into a two-sided random error that captures the random effects outside the control of the firm (the decision making unit) and a one-sided efficiency component. The model was first proposed by Meeusen and van den Broeck (1977) and Aigner et al. (1977). Assuming a suitable production function, the general functional form of the model is as follows.

$$
Y_{i}=f\left(X_{i}, \alpha\right)+\varepsilon_{i}
$$

Where, $Y_{i}$ is the level of output of the $i^{\text {th }}$ sample farm, $X_{i}$ is the value of input of the $i^{\text {th }}$ sample farm, $\alpha$ is unknown parameters to be estimated and $\varepsilon_{\mathrm{i}}$ is the error term that is composed of two independent elements $\mathrm{V}_{\mathrm{i}}$ and $\mathrm{U}_{\mathrm{i}}$, such that $\varepsilon_{\mathrm{i}}$ $=\mathrm{V}_{\mathrm{i}}-\mathrm{U}_{\mathrm{i}}$. The composite error term $\mathrm{V}_{\mathrm{i}}$ is the two-sided error term, and $U_{i}$ is the one-sided error term. The components of the composed error term are governed by different assumptions about their distribution. The random (symmetric) component $\mathrm{V}_{\mathrm{i}}$ is assumed to be identically and independently distributed as $N\left(0, \sigma_{v}{ }^{2}\right)$ and is also independent of $\mathrm{U}_{\mathrm{i}}$. This random error represents random variations in output due to factors outside the control of the farmers reflecting luck, weather, natural disaster, machine breakdown and variable input quality as well as the effects of measurement errors in the output variable, statistical noise and omitted variables from the functional form (Aigner et al. 1977). Following Battese and Coelli (1995) the $U_{i}$ is nonnegative random variable that represents the stochastic shortfall of outputs from the most efficient production. Therefore, $U_{i}$ is associated with the technical inefficiency of the farmers and are assumed to be independently and identically distributed truncations of the half normal distribution as $N\left(0, \sigma_{u}^{2}\right)$ and also independently distributed of $\mathrm{V}_{\mathrm{i}} \mathrm{s}$.

The parameters of the stochastic frontier model can be consistently estimated by the maximum-likelihood estimation method. The variance of the parameters of the likelihood function are estimated as

$$
\sigma_{s}^{2}=\sigma_{v}^{2}+\sigma_{u}^{2}
$$

and

$$
\gamma=\sigma_{u}^{2} / \sigma_{s}^{2}=\sigma_{u}^{2} /\left(\sigma_{v}^{2}+\sigma_{u}^{2}\right)
$$

Some empirical studies have attempted to analyze production risk and technical efficiency in a single framework. Kumbhakar, (1993) demonstrated a method to estimate production risk and technical efficiency using a flexible production function to represent the production technology. Battese et al. (1997) specified a stochastic frontier production function with an additive heteroskedastic error structure that is adopted in the present study. The model of Kumbhakar, (1993) permits negative or positive marginal effects of inputs on production risk which is consistent with the Just and Pope (1978) framework. Following their studies, the error specification in equation (1) is

$$
\varepsilon_{i}=g\left(X_{i}, \beta\right)\left[V_{i}-U_{i}\right]
$$

Thus, from equation (1) and (2) we have

$$
Y_{i}=f\left(X_{i}, \alpha\right)+g\left(X_{i}, \beta\right)\left[V_{i}-U_{i}\right]
$$

Equation (3) is the specification of the stochastic frontier production function with flexible risk properties (Battese et $a l .$, 1997). The mean and variance (risk function) of output of the $i^{\text {th }}$ farmer given the values of inputs and technical inefficiency effect can be estimated as

$$
E\left(Y_{i} \backslash X_{i}, U_{i}\right)=f\left(X_{i}, \alpha\right)-g\left(X_{i}, \beta\right) U_{i}
$$

and

$$
\operatorname{Var}\left(Y_{i} \backslash X_{i}, U_{i}\right)=g^{2}\left(X_{i}, \beta\right)
$$

Using this variance (risk function), the marginal production risk can be obtained by partial derivative of variance of production with respect to inputs which can be either positive or negative. That is

$$
\frac{\partial \operatorname{Var}\left(Y_{i} \backslash X_{i}, U_{i}\right)}{\partial X_{i j}}>0, \text { or }<0
$$

Accordingly, the technical efficiency of the $i^{\text {th }}$ farmer $\left(\mathrm{TE}_{\mathrm{i}}\right)$ is defined by the ratio of the mean production for the $i^{\text {th }}$ farmer (given the values of the inputs, $X_{i}$, and its technical inefficiency effect, $U_{i}$ ) to the corresponding mean maximum possible production (production with no technical inefficiency) can be specified as

$$
T E_{i}=\frac{E\left(Y_{i} \backslash X_{i}, U_{i}\right)}{E\left(Y_{i} \backslash X_{i}, U_{i}=0\right)}=1-T I_{i}
$$


Where $T I_{i}$ is technical inefficiency defined as potential output loss and represented as

$$
T I_{i}=\frac{U_{i} \cdot g\left(X_{i}, \beta\right)}{E\left(Y_{i} \backslash X_{i}, U_{i}=0\right)}=\frac{U_{i} \cdot g\left(X_{i}, \beta\right)}{f\left(X_{i}, \alpha\right)}
$$

If the parameters of the stochastic frontier production function are known, the best predictor of $U_{i}$ would be the conditional expectation of $\mathrm{TE}_{\mathrm{i}}$, given the realized value of the random variable $E_{i}=V_{i}-U_{i}$ (Jondrow et al. 1982). It can be shown that $U_{i} \backslash\left(V_{i}-U_{i}\right)$ is distributed as $N\left(\mu_{i}^{*}, \sigma_{*}^{2}\right)$, where $\mu_{i}^{*}$ and $\sigma_{*}{ }^{2}$ are defined by

$$
\begin{gathered}
\mu_{i}^{*}=-\frac{\left(V_{i}-U_{i}\right) \sigma_{u}{ }^{2}}{\left(1+\sigma_{u}^{2}\right)} \\
\sigma_{*}^{2}=\frac{\sigma_{u}^{2}}{\left(1+\sigma_{u}{ }^{2}\right)}
\end{gathered}
$$

It can also be shown that $E\left[U_{i} \backslash\left(V_{i}-U_{i}\right)\right]$, denoted by $\hat{U}_{i}$ is

$$
\hat{U}_{i}=\mu_{i}^{*}+\sigma_{*}\left[\frac{\varphi\left(\mu_{i}^{*} / \sigma_{*}\right)}{\Phi\left(\mu_{i}^{*} / \sigma_{*}\right)}\right]
$$

Where, $\varphi($.$) and \Phi($.$) represent the density and$ distribution functions of the standard normal random variable. Equation (11) can be estimated using the corresponding predictors for the random variable, $\mathrm{E}_{\mathrm{i}}$, given by

$$
\hat{E}_{i}=\frac{Y_{i}-f\left(X_{i}, \hat{\alpha}\right)}{g\left(X_{i}, \hat{\beta}\right)}
$$

After estimating equation (11), equation (8) can be estimated as

$$
T I_{i}=\frac{\hat{U}_{i} \cdot g\left(X_{i}, \hat{\beta}\right)}{f\left(X_{i}, \hat{\alpha}\right)}
$$

The technical efficiency of the $i$ th farmer is predicted by $T \hat{E}_{i}=1-T \hat{I}_{i}$. Technical efficiency of the $i$ th farmer can also be calculated as $\mathrm{TE}_{\mathrm{i}}=\exp \left(-\mathrm{U}_{\mathrm{i}}\right) * 100(\mathrm{TE}$ is converted into percentage through multiplying this equation by 100). It is calculated using the conditional expectation of the above equation, conditioned on the composite error $\left(\varepsilon_{\mathrm{i}}=\mathrm{V}_{\mathrm{i}}-\mathrm{U}_{\mathrm{i}}\right)$.

\subsection{Empirical Specification of the Translog Production Function Model}

Empirically, Translog stochastic production frontier model is employed in this study to estimate the level of technical efficiency of rice producing farms in the study area. For this purpose, total amount of boro rice production of farmers are taken as dependent variable and inputs of boro rice production used by farmers are incorporated as independent variables. Thus, following Villano and Fleming (2004), the empirical model for the present study is specified as

$$
\ln Y_{i}=\beta_{0}+\sum_{j=1}^{6} \beta_{j} \ln X_{j i}+0.5 \sum_{j=1}^{6} \sum_{k=1}^{6} \beta_{j k} \ln X_{j i} \ln X_{k i}+V_{i}-U_{i}
$$

Where, $\mathrm{Y}=$ total production of boro rice (mound), $\mathrm{X}_{1}=$ farm size (bigha), $\mathrm{X}_{2}=$ cost of labor used in boro rice cultivation (Tk., Bangladeshi currency), $\mathrm{X}_{3}=$ cost of fertilizer and pesticide used to produce rice (Tk.), $X_{4}=$ cost of seed planted to produce rice (Tk.), $X_{5}=$ irrigation cost (Tk.), $X_{6}=$ ploughing cost (Tk.), and $\beta_{\mathrm{j}}$ s are unknown parameters to be estimated.

The Translog production function is the most frequently used flexible functional form in efficiency analysis in recent years. It is considered as more general function due to its flexible functional form. It permits the partial elasticities of substitution between inputs to vary, i.e. the elasticity of scale can vary with output and factor proportions. On the other hand, Cobb-Douglas functional form imposes severe restrictions on the use of technology by restricting the production elasticities to be constant and the elasticities of inputs substitution to be unity implying that capital and labor are substitutable in both the short and the long run. Another commonly used production function is Constant Elasticity of Substitution (CES) production function. Unlike CobbDouglas production function, the CES production function permits one to vary the elasticity of substitution (Villano and Fleming, 2004).

\section{Description of Data}

In the present study, data on output and inputs are used to estimate farm level technical efficiency of rice production. Before estimation, some properties of data such as mean, minimum and maximum are calculated. The properties of data are shown in Table 1.

From Table 1 it is seen that the mean farm size of sample farmers is 5.77 bighas with minimum of 1.50 bighas and maximum of 20 bighas in the study area. Again, the average labor cost, fertilizer cost, pesticide cost, seed cost, irrigation cost and ploughing cost are Tk.3240, Tk.1920, Tk.302.26, Tk.491.22, Tk.2700 and Tk.1078.32, respectively, of sample farmers.

Table 1. Description of Collected Data.

\begin{tabular}{llll}
\hline Subject & Mean & Minimum & Maximum \\
\hline Farm size (bigha) & 5.77 & 1.50 & 20.00 \\
Labour cost (Tk.) & 3240 & 3000.00 & 4200 \\
Fertilizer cost (Tk.) & 1920 & 1220.00 & 2800.00 \\
Pesticide cost (Tk.) & 302.26 & 130.00 & 500.00 \\
Seed cost (Tk.) & 491.22 & 240.00 & 780.00 \\
Irrigation cost (Tk.) & 2700 & 2500.00 & 2800.00 \\
Ploughing cost (Tk.) & 1078.32 & 800.00 & 1500.00 \\
Per bigha production & 28.02 & 20.00 & 35.00 \\
(Mound) & & & \\
\hline
\end{tabular}

Source: Authors own calculation

Table 1 also reveals that the average production of boro rice per bigha in the study area is 28.02 mounds with minimum of 20 mounds and maximum of 35 mounds in the study area. 


\section{Discussion of Results}

The estimated results of the stochastic frontier production function are discussed in this section. Maximum Likelihood (ML) method is applied to estimate the coefficients of Translog production function. The findings of the present study are compared with those of the earlier studies to check the variation of the results found in the present study.

\subsection{Technical Efficiency of Boro Rice Production}

Table 2. Technical Efficiency (TE) of Boro Rice Production in the Study Area.

\begin{tabular}{lll}
\hline Technical efficiency (\%) & No. of farm & \% of farm \\
\hline $51-60$ & 0 & 0 \\
$61-70$ & 1 & 0.87 \\
$71-80$ & 9 & 7.83 \\
$81-90$ & 52 & 45.22 \\
$91-100$ & 53 & 46.09 \\
Total & 115 & 100.0 \\
Mean TE (\%) & 89.5 & \\
Minimum TE (\%) & 69.8 & \\
Maximum TE (\%) & 99 & \\
\hline
\end{tabular}

Source: Authors own calculation

Technical efficiency of all sample farms is estimated using the Translog production function and it is classified into five categories on the basis of efficiency level. The estimated results of technical efficiency of boro rice farms are summarized in Table 2. From the table it is observed that the average level of technical efficiency of sample boro rice farms is $89.6 \%$ with minimum efficiency of $69.8 \%$ and maximum efficiency of $99 \%$.

From the above table it is also found that among all sample farms there are only $0.87 \%$ farms within the efficiency level between $61 \%-70 \%$ and $7.83 \%$ farms within the efficiency level between $71 \%-80 \%$. It is interesting that most of the farms, around $91.31 \%$, have been operating between the efficiency level $81 \%-100 \%$.

However, the average level of technical efficiency of the sample farms indicates that there is a certain level of technical inefficiency in boro rice production in the study area. This result suggests that in the short run it is possible to increase the amount of boro rice production in the study area by increasing the efficiency level. Farmers may increase the level of efficiency of their farms by controlling the use of inputs of production that have significant contribution to influence efficiency level of production. For this purpose, it is essential to identify the significant inputs of production which have positive or negative contribution to production. In section 5.2, significant factors of production are estimated using Translog production function.

\subsection{Results of Translog Production Function}

Table 3. Maximum Likelihood Estimation for Boro Rice Farms.

\begin{tabular}{|c|c|c|c|c|}
\hline Variables & Parameters & Coefficients & Standard error & t-ratio \\
\hline Constant & $\beta_{0}$ & $10.51^{*}$ & 1.72 & 6.13 \\
\hline In farm size & $\beta_{1}$ & 1.05 & 0.57 & 1.83 \\
\hline $\ln$ labor & $\beta_{2}$ & $0.002 *$ & 0.0004 & 4.66 \\
\hline In fertilizer \& pesticide & $\beta_{3}$ & $-0.01 *$ & 0.004 & -2.97 \\
\hline $\ln$ seed & $\beta_{4}$ & $0.19^{*}$ & 0.03 & 5.73 \\
\hline ln irrigation & $\beta_{5}$ & $0.001 * *$ & 0.001 & 2.29 \\
\hline In ploughing & $\beta_{6}$ & 0.0001 & 0.0003 & 0.44 \\
\hline$(\ln \text { labor })^{2}$ & $\beta_{8}$ & 0.37 & 0.43 & 0.85 \\
\hline$(\ln \text { fertilizer \& pesticide })^{2}$ & $\beta_{9}$ & 0.26 & 0.70 & 0.37 \\
\hline$(\ln \text { seed })^{2}$ & $\beta_{10}$ & 0.14 & 0.36 & 0.40 \\
\hline$(\ln \text { irrigation })^{2}$ & $\beta_{11}$ & $1.00 * * *$ & 0.49 & 2.03 \\
\hline (ln ploughing) ${ }^{2}$ & $\beta_{12}$ & 0.17 & 0.17 & 1.01 \\
\hline ln farm size*ln labour & $\beta_{13}$ & -0.25 & 0.13 & -1.90 \\
\hline ln farm size* $\ln$ fertilizer $\&$ pesticide & $\beta_{14}$ & 0.03 & 0.16 & 0.19 \\
\hline In farm size*ln seed & $\beta_{15}$ & 0.15 & 0.14 & 1.09 \\
\hline In farm size* In ploughing & $\beta_{17}$ & -0.01 & 0.16 & -0.04 \\
\hline In labour*In fertilizer $\&$ pesticide & $\beta_{18}$ & $1.15^{*}$ & 0.20 & 5.83 \\
\hline In labour*ln seed & $\beta_{19}$ & -0.15 & 0.43 & -0.36 \\
\hline ln labour*ln irrigation & $\beta_{20}$ & -0.50 & 0.58 & -0.86 \\
\hline ln labour*In ploughing & $\beta_{21}$ & 0.11 & 0.38 & 0.29 \\
\hline $\ln$ fertilizer $\&$ pesticide $* \ln$ seed & $\beta_{22}$ & -0.12 & 0.58 & -0.21 \\
\hline In fertilizer \& pesticide $* \ln$ irrigation & $\beta_{23}$ & -0.20 & 0.47 & -0.42 \\
\hline In fertilizer \& pesticide $*$ In ploughing & $\beta_{24}$ & 0.53 & 0.27 & 1.93 \\
\hline $\ln$ seed $* \ln$ irrigation & $\beta_{25}$ & 0.20 & 0.40 & 0.50 \\
\hline ln seed*ln ploughing & $\beta_{26}$ & 0.00002 & 0.48 & 0.0001 \\
\hline In irrigation*ln ploughing & $\beta_{27}$ & 0.18 & 0.43 & 0.43 \\
\hline Sigma-squared & $\sigma^{2}$ & $0.01 *$ & 0.001 & 5.93 \\
\hline Gamma & $\gamma$ & $0.97 *$ & 0.35 & 2.82 \\
\hline Log likelihood function: 152.21 ; LR: 25.76 & & & & \\
\hline
\end{tabular}

Source: Authors own calculation; Note: ${ }^{*}, * *, * *$ indicates $1 \%, 5 \%$ and $10 \%$ level of significance

Production of boro rice is generally affected by some factors such as farm size, labor cost, fertilizer and pesticide 
cost, seed cost, irrigation cost, ploughing cost etc. The estimated effects of these factors are shown in Table 3.

From Table 3 it is found that the estimated coefficients of labor cost, fertilizer and pesticide cost, seed cost and irrigation cost are statistically significant. This indicates that these factors of production are the major determinants that affect boro rice production in the study area. The sign of coefficients of all these variables is positive except fertilizer and pesticide cost. On the other hand, the coefficients of farm size and ploughing cost are statistically insignificant. So, farm size and ploughing cost do not bear any significant meaning to affect boro rice production.

In Table 3 coefficient of labor is found 0.002 indicating that a $1 \%$ increase in labor cost may increase output by $0.002 \%$. Similarly, coefficient of seed cost and irrigation costs are 0.19 and 0.001 , respectively, indicating that a $1 \%$ increase in seed cost and irrigation cost may increase output by $0.19 \%$ and $0.001 \%$, respectively. Again, coefficient of fertilizer and pesticide cost is -0.01 indicating that a $1 \%$ increase in fertilizer and pesticide cost may decrease output by $0.01 \%$. The negative coefficient of fertilizer and pesticide cost may seem interesting but it is also similar to the findings of Islam et al. (2004), Backman et al. (2010), Khan et al. (2010) in case of Bangladeshi farms.

Among six square parameters only the coefficient of irrigation square is statistically significant and has positive sign. It means that an increase in irrigation cost will increase boro rice production at an increasing rate. Other square parameters are statistically insignificant. From Table 3 it is also found that among the interactive variables 'farm size*irrigation' and 'labor*fertilizer and pesticide' are significant at $1 \%$ level and have also positive sign. Besides, 'farm size*labor' and 'fertilizer and 'pesticide*ploughing' are significant at $10 \%$ significance level and have negative and positive sign, respectively. Moreover, coefficients of other interactive variables are statistically insignificant indicating no significant meaning in explaining boro rice production. The estimated value of $\gamma$ is found as 0.97 , which means that $97 \%$ of the total variation in rice output is due to technical inefficiency. It means that about $97 \%$ of the discrepancies between observed output and the frontier output are due to technical inefficiency.

\section{Conclusion}

Estimation of production efficiency is important to increase the productivity of agriculture sector in a developing country like Bangladesh. The present study finds that the average level of technical efficiency of boro rice farms in the study area is $89.5 \%$. This result means that the boro rice farms in the study area have been operating below the maximum level of production frontier. Given the available technology, farmers can increase their production by $10.5 \%$. The estimated results of Translog production function shows that labor cost, seed cost and irrigation cost have positive and significant effect on the level of technical efficiency of boro rice production in the study area. Thus, farmers may increase production level by increasing the use of these inputs. On the other hand, fertilizer and pesticide cost is found as negative contributor to the level of production efficiency. This result might indicate that fertilizer and pesticides are being used at high doses by the farmers in the study area and therefore, they should use these inputs with appropriate doses. Thus, on the basis of the findings of the present study, it can be suggested that the government and non-government organizations operating in the study area should make the farmers aware about proper use of inputs of boro rice production to increase the level of technical efficiency.

\section{References}

[1] Adedeji, I. A., Kazeem .O., Adelalu, S.I., Ogunjimi, A.O. and Otekunrin (2013). Application of stochastic production frontier in the estimation of technical efficiency of poultry egg production in Ogbomoso metropolis of Oyo state, Nigeria. World Journal of Agricultural Research. 1(6), 119-123.

[2] Aigner, D. J., Lovell, C. A. K., and Schmidt, P. (1977). Formulation and estimation of stochastic frontier production function models. Journal of Econometrics, 6(1), 21-37.

[3] Ajibefun, I. A., and Abdulkadri, A. O. (1999). An investigation of technical inefficiency and production of farmers under the national directorate of employment in Ondo State, Nigeria. Applied Economics Letter, 6, 111-114.

[4] Ajibefun, I. A., and Daramola, A. G. (1999). Measurement and source of technical inefficiency in poultry egg production in Ondo State, Nigeria. Journal of Economics and Rural Development, 13, 85-94.

[5] Ajibefun, I. A., Battese, G.E., and Daramola, A. G. (2002). Determinants of technical efficiency in smallholder food crop farming: application of stochastic frontier production function. Q. J. Int. Agric., 41(3), 225-240.

[6] Anonymous (2009). Annual Report for (2008). IRRI, Los Banos, Philippines.

[7] Backman, S., Islam, K. M. Z., and Sumelius, J. (2010). Determinants of technical efficiency of rice farms in NorthCentral and North-Western Regions in Bangladesh. An unpublished paper.

[8] Battese, G. E., and Coelli, T. J. (1988). Prediction of farmlevel technical efficiencies with a generalized frontier production functions and panel data. Journal of Econometrics, $38,387-399$.

[9] Battese, G. E., Rambaldi, A. N., and Wan, G. H. (1997). Stochastic frontier productions function with flexible risk properties. Journal of Productivity Analysis, 8, 269-280.

[10] BBS (2010). Statistical Yearbook of Bangladesh. Bangladesh Bureau of Statistics, Statistics Division, Ministry of Planning, Government of the People's Republic of Bangladesh, Dhaka, Bangladesh.

[11] BBS (2013). Statistical Yearbook of Bangladesh. Bangladesh Bureau of Statistics, Statistics Division, Ministry of Planning, Government of the People's Republic of Bangladesh, Dhaka, Bangladesh. 
[12] Bravo-Ureta, B. E., and Pinheiro, A. E. (1993). Efficiency analysis of developing country agriculture: A review of the frontier function literature. Agricultural and Resource Economics Review, 22(1), 88-101.

[13] BRRI, (2000). Annual report, Bangladesh Rice Research Institute, Gaziupur, Bangladesh.

[14] Chirwa, W. E. (2007). Sources of technical efficiency among smallholder maize farmers in Southern Malawi. African Economic Research Consortium, Nairobi, AERC Research Paper 172.

[15] Coelli, T., Rao, P. D. S., and Battese, G. E. (1998). An introduction to efficiency and productivity analysis. London: Kluwer Academic Publisher.

[16] FAOSTAT (2012). Food and Agricultural Commodities Production 2010. Food and Agriculture Organization of the United Nations. Available at http://faostat. fao.org/site/339/ default.aspx.

[17] FAPRI (2009). The Agricultural Outlook 2009. World Rice. Food and Agricultural Policy Research Institute. Available at http://www.fapri. iastate. Edu/outlook/2009/.

[18] Forsund, F. R., Lovell, C. A. K., and Schmidt, P. (1980). A survey of frontier production functions and of their relationship to efficiency measurement. Journal of Econometrics, 13, 5-25.

[19] GoB (2014). Bangladesh Economic Review 2008. Ministry of Finance, Government of the People's Republic of Bangladesh, Dhaka.

[20] Hasan, F. M. (2008). Economic efficiency and constraints of maize production in the Northern Region of Bangladesh. $j$. innov.dev.strategy. 2(1), 18-32.

[21] Hossain, M. E., and Rahman, Z. (2012). Technical efficiency analysis of rice farmers in Naogaon district: An application of the stochastic frontier approach. Journal of Economics and Development Studies, 1(1), 1-20.

[22] Islam, R. M., Hossain, M., and Jaim, H. M. W. (2004). Technical efficiency of farm producing transplanted aman rice in Bangladesh: A comparative study of aromatic, fine and coarse varieties. Bangladesh Journal of Agricultural Economics, XXVII (2), 1-24.

[23] Jondrow, J., Lovell, C. A. K., Materov, I. S., and Schmidt, P. (1982). On the estimation of technical inefficiency in the stochastic frontier production function model. Journal of Econometrics, 19, 233-238.

[24] Just, R. E., and Pope, R. D. (1978). Stochastic specification of production functions and economic implications. Journal of Econometrics, 7, 67-86.
[25] Khan, A., Huda, A. F., and Alam, A. (2010). Farm household technical efficiency: A study on rice producers in selected areas of Jamalpur District in Bangladesh. European Journal of Social Sciences, 14(2), 262-271.

[26] Kothari, C. R. (2003). Research methodology method and technique. New Delhi. Wishwa Prakashan.

[27] Kumbhakar, S. C. (1993). Production risk, technical efficiency, and panel data. Economics Letters, 41, 11-16.

[28] Meeusen, W., and van den Broeck, J. (1977). Efficiency estimation from Cobb-Douglas production function with composed error. International Economic Review, 18, 435-444.

[29] Mohapatra, R. (2013). Farm level technical efficiency in paddy production: A translog frontier production function approach. International Journal of Advanced Research, 1(3), 300-307.

[30] Nargis, F., and Lee, S. H. (2013). Efficiency analysis of boro rice production in North-central region of Bangladesh. The Journal of Animal \& Plant Sciences, 23(2), 527-533.

[31] Parikh, A., and Shah, M. K. (1994). Measurement of technical efficiency in the northwest frontier province of Pakistan. Journal of Agricultural Economics, 45, 132-138.

[32] Sattar, A. (2000). Bridging the rice yield gap in Bangladesh. In bridging the rice yield gap in Asia and the Pacific. RAP Publication, 2000/16.

[33] Shantha, A. A., Ali, A. B. G. H., and Bandara, R. A. G. (2013). Technical efficiency of paddy farming under major irrigation conditions in the dry-zone of Sri Lanka: A parametric approach. Australian Journal of Basic and Applied Sciences, 7(6), 104-112.

[34] Sharma, K. R., Leung, P., and Zalleski, H. M. (1999). Technical, allocative, and economic efficiencies in swine production in Hawaii: A comparison of parametric and nonparametric approaches. Agricultural Economics, 20(1), 23-35.

[35] Tijani, A. A. (2006). Analysis of the technical efficiency of rice farms in Ijesha Land of Osun State, Nigeria. Agrekon, 45(2).

[36] Udoh, E. J., and Akintola, J. O. (2001). Land management and resource use efficiency among farmers in South Eastern Nigeria". Award winning paper presented to the African Real Estate Society and the Rics foundation. Elshadai Global Ventures Ltd., 20-32.

[37] Villano, R., and Fleming, E. (2004). Analysis of technical efficiency in a rainfed low land rice environment in Central Luzon, Philippines using a stochastic frontier production function with a heteroskedastic error structure. Working Paper series in agricultural and resource Economics, University of New England. 